\title{
SALUD MENTAL Y MIGRACIÓN EN LAS AMÉRICAS
}

\section{Julio TORALES ${ }^{1}$.}

${ }^{1}$ Profesor Jefe de Cátedra de Socioantropología (Filial Santa Rosa del Aguaray) y Profesor Asistente de Psiquiatría, Facultad de Ciencias Médicas, Universidad Nacional de Asunción, San Lorenzo - Paraguay. Editor Jefe, Revista Medicina Clínica y Social.

Cómo citar este artículo: Torales J. Salud mental y migración en las Américas. Medicina Clínica y Social. 2017;1(2):101-102.

Recientemente, investigadoras de la Facultad de Medicina Clínica Alemana (Universidad del Desarrollo) de Chile han Ilamado la atención sobre los desafíos que plantea la migración para los sistemas de salud y, principalmente, sobre la necesidad de dotar a los trabajadores de salud de competencias culturales para la atención de poblaciones migrantes (1) en Chile. Lo anterior, se aplica a todo el continente. Se estima que América Latina tiene más de 16 millones de migrantes, que se encuentran en movimiento debido a factores económicos, educacionales, políticos, entre otros (2).

Un aspecto específico de la salud de las personas migrantes es la atención de su salud mental. En las Américas, los principales problemas de salud mental a los que se ve expuesta la población migrante son ansiedad, depresión, abuso y dependencia de sustancias, trastorno de estrés postraumático, suicidio e intento suicida $(3,4)$. Asimismo, investigaciones realizadas en el continente americano muestran niveles de estrés crónico entre el $21 \%$ y el $34 \%$ de los migrantes, constituyéndose esto en un factor predisponente que puede interferir negativamente en la salud mental de este grupo vulnerable (5).

A fin de poder brindar una atención en salud mental coherente con los principios de la práctica médica, de la ética y del respeto a los derechos humanos de los migrantes americanos, los gobiernos de América Latina y el Caribe deben proveer recursos adecuados para el diseño y ejecución de planes de salud mental para esta población, específicamente destinados a evaluar las necesidades médicas, psicológicas y sociales de las personas migrantes, desarrollando además colaboraciones inter-sectoriales (2).

Asimismo, todos los trabajadores de la salud mental deben recibir entrenamiento en competencias culturales. Esto solo podrá ser posible si los gobiernos nacionales destinan los recursos adecuados a dicho fin. Además, aspectos relativos a la salud mental de las personas migrantes ( $y$ también de los refugiados y solicitantes de asilo), deben formar parte del plan de estudios de médicos generales, psiquiatras, psicólogos, enfermeros y trabajadores sociales, en los niveles del grado y del postgrado, resaltándose que el entrenamiento en sensibilidad cultural debe ser parte fundamental de la educación de todos los profesionales de la salud (2).

Los trabajadores de la salud mental deben ser capaces de recolectar toda la información posible acerca del estado de las personas antes del proceso migratorio, incluyendo no sólo factores de riesgo (migración forzada, violencia, inseguridad económica, soledad, entre otros) 
sino también factores protectores (como la resiliencia y las redes sociales de apoyo). Por último, la educación a las comunidades receptoras, que incluya aspectos específicos acerca de la salud mental, debe ser potenciada y ofrecida de manera urgente, con el fin de hacer frente al estigma y a la discriminación que sufren las personas migrantes.

Todo lo anterior se hace necesario para dar una respuesta adecuada a la atención en salud mental de los migrantes, considerando que cada uno de ellos es una persona con una historia y vulnerabilidades propias que afectan todos los aspectos de su vida biopsicosocial.

\section{CONFLICTOS DE INTERÉS Y FUENTE DE FINANCIACIÓN}

El autor declara no poseer conflictos de interés. Fuente de financiación: ninguna.

\section{REFERENCIAS BIBLIOGRÁFICAS}

1. Bernales M, Cabieses B, McIntyre AM, Chepo M. Desafíos en la atención sanitaria de migrantes internacionales en Chile. Rev Peru Med Exp Salud Publica. 2017;34(2):167175. http://.dx.doi.org/10.17843/rpmesp.2017.342.2510

2. Bhugra D, Córdoba R, Torales J, Castaldelli-Maia J, Mendoza E, Chamorro R, et al. Declaración de Bogotá sobre Migración y Salud Mental [Internet]. Bogotá: Asociación Psiquiátrica de América Latina; 2016 [citado el 17 de julio de 2017]. URL.

3. Patterson B, Kyu H, Georgiades K. Age at Immigration to Canada and the Occurrence of Mood, Anxiety, and Substance Use Disorders. Can J Psychiatry. 2012;57(4):210-217. http://.dx.doi.org/10.1177/070674371305800406

4. Bhugra D, Gupta S, Bhui K, Craig T, Dogra N, Ingleby D, et al. WPA guidance on mental health and mental care in migrants. World Psychiatry. 2011;10(1):2-10. http://.dx.doi.org/10.1002/j.2051-5545.2011.tb00002.x

5. Pozos-Radillo BE, Aguilera-Velasco $M$, Acosta-Fernández M, Pando-Moreno M. Perfil de estrés y estrés crónico en migrantes mexicanos en Canadá. Rev Salud Pública. 2014;16(1):63-75. http://.dx.doi.org/10.15446/rsap.v16n1.35812 


\section{MENTAL HEALTH AND MIGRATION IN THE AMERICAS}

\section{Julio TORALES ${ }^{1}$.}

${ }^{1}$ Head of the Socio-anthropology Department (Santa Rosa Campus) and Professor of Psychiatry, School of Medical Sciences, National University of Asunción, San Lorenzo - Paraguay. Editor-in-Chief, Journal Medicina Clínica y Social.

How to cite this article: Torales J. Salud mental y migración en las Américas. Medicina Clínica y Social. 2017;1(2):101-102.

Recently, researchers of the School of Medicine "Clínica Alemana" (Universidad del Desarrollo) have drawn attention to the challenges posed by migration to the health systems and, above all, to the need to equip health workers with cultural competencies for the care of migrant populations (1) in Chile. This applies to the whole continent. It is estimated that Latin America has more than 16 million migrants, who are in movement due to economic, educational, and political factors, among others (2).

A specific aspect of the health of migrants is their mental health care. In the Americas, the main mental health problems to which the migrant population is exposed are anxiety, depression, substance abuse and dependence, posttraumatic stress disorder, suicide and suicide attempt $(3,4)$. Similarly, investigations carried out in the Americas show chronic stress levels between $21 \%$ and $34 \%$ of migrants, a predisposing factor that may negatively interfere with the mental health of this vulnerable group (5).

In order to be able to provide mental health care consistent with the principles of medical practice, ethics and respect for human rights of American migrants, governments in Latin America and the Caribbean must provide adequate resources for the design and implementation of mental health plans for this population, specifically designed to assess the medical, psychological and social needs of migrants, and to develop inter-sectoral partnerships (2).

In addition, all mental health workers must be trained in cultural competencies. This can only be possible if national governments allocate adequate resources for this purpose. Moreover, aspects relating to the mental health of migrants (as well as refugees and asylum seekers) should be part of the curriculum of general practitioners, psychiatrists, psychologists, nurses and social workers at undergraduate and postgraduate education, emphasizing that training in cultural sensitivity should be a fundamental part of the education of all health professionals (2).

Mental health workers should be able to gather as much information as possible about the state of the people before the migration process, including not only risk factors (forced migration, violence, economic insecurity, loneliness, among others) but also protective factors (such as resilience and social support networks). Finally, education of the receiving communities, including specific aspects of mental health, should be strengthened and offered urgently in order to address stigma and discrimination faced by migrants. 
All of the above is necessary to give an adequate response to the mental health care of migrants, considering that each of them is a person with an own history and vulnerabilities that affect all aspects of his/her biopsychosocial life.

\section{CONFLICTS OF INTEREST AND FUNDING}

Conflicts of interest: none. Funding source: none.

\section{REFERENCES}

1. Bernales M, Cabieses B, McIntyre AM, Chepo M. Desafíos en la atención sanitaria de migrantes internacionales en Chile. Rev Peru Med Exp Salud Publica. 2017;34(2):167175. http://.dx.doi.org/10.17843/rpmesp.2017.342.2510

2. Bhugra D, Córdoba R, Torales J, Castaldelli-Maia J, Mendoza E, Chamorro R, et al. Declaración de Bogotá sobre Migración y Salud Mental [Internet]. Bogotá: Asociación Psiquiátrica de América Latina; 2016 [citado el 17 de julio de 2017]. URL.

3. Patterson B, Kyu H, Georgiades K. Age at Immigration to Canada and the Occurrence of Mood, Anxiety, and Substance Use Disorders. Can J Psychiatry. 2012;57(4):210-217. http://.dx.doi.org/10.1177/070674371305800406

4. Bhugra D, Gupta S, Bhui K, Craig T, Dogra N, Ingleby D, et al. WPA guidance on mental health and mental care in migrants. World Psychiatry. 2011;10(1):2-10. http://.dx.doi.org/10.1002/j.2051-5545.2011.tb00002.x

5. Pozos-Radillo BE, Aguilera-Velasco M, Acosta-Fernández M, Pando-Moreno M. Perfil de estrés y estrés crónico en migrantes mexicanos en Canadá. Rev Salud Pública. 2014;16(1):63-75. http://.dx.doi.org/10.15446/rsap.v16n1.35812 